\title{
Effects of Cyphomandra betacea Seedlings Intercropping with F1 Generations of Solanum photeinocarpum on Soil Enzyme Activity under Cadmium Stress
}

\author{
Shiyao Shan ${ }^{1,}$, Mengyao Li ${ }^{1, b}$ and Lijin Lin',c* \\ ${ }^{1}$ College of Horticulture, Sichuan Agricultural University, Chengdu, Sichuan, China \\ ${ }^{2}$ Institute of Pomology and Olericulture, Sichuan Agricultural University, Chengdu, Sichuan, China \\ a1519312547@qq.com, b497533314@qq.com, cllj800924@qq.com \\ ${ }^{*}$ Corresponding author. Shiyao Shan and Mengyao Li contributed equally to this work.
}

\begin{abstract}
Keywords: Cyphomandra betacea; Solanum photeinocarpum; Intercropping; Soil enzyme activity Abstract: Effects of Cyphomandra betacea seedlings intercropping with $\mathrm{F}_{1}$ generations of Solanum photeinocarpum on soil enzyme activity under cadmium $(\mathrm{Cd})$ stress were studied. The activities of soil catalase, soil polyphenol oxidase, soil sucrase, and soil urease were measured. The results showed that under $\mathrm{Cd}$ stress, $C$. betacea seedlings intercropping with $\mathrm{F}_{1}$ generation of $S$. photeinocarpum increased soil polyphenol oxidase and decreased soil catalase activities. C. betacea seedlings intercropping $S$. photeinocarpum of mine ecotype and two $\mathrm{F}_{1}$ generations of $S$. photeinocarpum enhanced soil sucrase activity. C. betacea seedlings intercropping two ecotypes $\mathrm{F}_{1}$ generations of $S$. photeinocarpum enhanced soil urease activity.
\end{abstract}

\section{Introduction}

Cyphomandra betacea belongs to Solanaceae, is a perennial evergreen fruit tree [1], also known as woody tomato, egg fruit, and sour eggplant. The fruit juicy sweet and sour of $C$. betacea can be used for fresh fruit, storage, transportation, is a natural green food, considerable economic benefits, great potential for development [2]. However, the frequent heavy metal pollution in recent years has threatened the growth of fruit trees and the safety of fruits in orchards, which is a major problem to be solved urgently.

At present, there are many methods for the remediation of soil heavy metal pollution, of which phytoremediation is a common method with the advantages of low cost and wide application range [3]. In agriculture, intercropping can improve the crop's efficient use of light, temperature, water, gas and fertilizer to reduce the incidence of pests and diseases and improve the yield and quality of crops [4].In addition, it can improve the soil environment, improve soil enzyme activity and crop nutrient absorption and utilization of soil [5]. When the two plant roots close to each other or contact, can produce "rhizosphere dialogue" phenomenon, this phenomenon can promote or inhibit plant growth [6]. Soil enzyme is a biocatalyst, which is sensitive biological index reflecting soil fertility. It can directly reflect the intensity and direction of soil biochemical processes. Under the condition of heavy metal pollution, heavy metal can occupy the active center of soil enzyme or is related to groups combine into complexes, affecting the enzyme activity in the soil, thereby reducing soil enzyme activity [7-8]. Studies have shown that soil enzyme activity and heavy metal concentrations showed a significant correlation, and its activity as an indicator of ecological effects of heavy metal pollution [9]. The effects of different plants (mixed) on the absorption of heavy metals are mainly concentrated in the rhizosphere. Plants can secrete organic acids by letter feedback and organic acids can form complexes with heavy metals [10], thus reducing the bioavailability of heavy metals, reducing the plant's absorption of heavy metals [11], which is also conducive to the improvement of soil enzyme activity.

Soil enzyme is a biocatalyst, which is a sensitive biological index reflecting soil fertility. It can directly reflect the intensity and direction of soil biochemical processes. However, the accumulation and distribution of heavy metal ions in the soil can easily affect the enzyme activity in the soil [3], the relevant research shows that heavy metals on soil enzyme activity has a strong inhibitory effect [4-6]. 
Hybrids affect plant uptake of heavy metals mainly by altering the physical and chemical properties of soil enzymes such as soil enzyme activity in the rhizosphere [7-8].

In view of this, the results showed that under the conditions of cadmium (Cd) treatment, the growth status of Solanum photeinocarpum parents and $S$. photeinocarpum positive and negative hybridization $F_{1}$ generation were observed. To study the effects of two ecotypes of $S$. photeinocarpum and its positive and negative hybridization $F_{1}$ generation on the soil enzyme activities in order to screen $S$. photeinocarpum hybridization $\mathrm{F}_{1}$ generation which can effectively repair $\mathrm{Cd}$ pollution in orchard soil and significantly reduce the $\mathrm{Cd}$ accumulation in tree and $C$. betacea, for orchard soil Cd pollution repair provide reference.

\section{Materials and Methods}

Materials. The seeds of $S$. photeinocarpum of mine ecotype were collected from a $S$. photeinocarpum plant at the lead-zinc mine of the Tangjiashan, Hanyuan County, Sichuan, China in October 2014. The seeds of $S$. photeinocarpum of farmland ecotype were collected from a $S$. photeinocarpum plant at the Ya'an campus farm of the Sichuan Agricultural University, China in November 2014.

Intercropping. In March 2015, the collected seeds were directly sown in a plastic basin of $21 \mathrm{~cm}$ $\times 20 \mathrm{~cm}$ (diameter $\times$ height). The soil for planting $S$. photeinocarpum of farmland ecotype was taken from the farm of Ya'an Campus of Sichuan Agricultural University and the soil for planting $S$. photeinocarpum of mine ecotype was taken from the Tangjiashan lead-zinc mine in Hanyuan County, Sichuan Province. When seedings were mature into the bud, we started hybridization. When the fruit reached physiological maturity, harvested the fruit for colleting the seeds.

Experimental Design. The soil samples were air-dried and passed through a $6.72 \mathrm{~mm}$ mesh in July 2015, and then $3.0 \mathrm{~kg}$ of soil was weighed into a $21 \mathrm{~cm} \times 20 \mathrm{~cm}$ (diameter $\times$ height) plastic basin. $\mathrm{Cd}$ was added to make a final soil $\mathrm{Cd}$ concentration of $10 \mathrm{mg} \cdot \mathrm{kg}^{-1}$ with a saturated heavy metal solution in the form of $\mathrm{CdCl}_{2} \cdot 2.5 \mathrm{H}_{2} \mathrm{O}$. Kept the soil moist for 30 days and mixed with soil from time to time to mix the soil well. In July 2015, C. betacea were bred in a climate chamber. In August 2015, the seeds of $S$. photeinocarpum parental generation and $S$. photeinocarpum positive and negative hybridization F1 generations of (about $3 \mathrm{~cm}$ tall, 2 euphyllas expanded) and C. betacea seedlings (about $10 \mathrm{~cm}$ tall, 3 euphyllas expanded) respectively were planted in pots. S. photeinocarpum planted 1 per pot. $C$. betacea seedlings planted 3 per pot for monoculture, and 2 per pot for intercropping. There were five treatments: $\mathrm{CK}(C$. betacea monoculture), $\mathrm{T} 1$ ( $C$. betacea intercropping $S$. photeinocarpum of farmland ecotype), T2 (C. betacea intercropping $S$. photeinocarpum of mine ecotype), T3 (C. betacea intercropping $S$. photeinocarpum positive hybridization $\mathrm{F}_{1}$ generation), and $\mathrm{T} 4$ (C. betacea intercropping $S$. photeinocarpum positive hybridization $F_{1}$ generation) Each treatment was repeated six times with a $15-\mathrm{cm}$ spacing between pots, and completely randomized. The soil moisture content was maintained at $80 \%$ of field capacity until the plants were harvested.

Determination Method. Soil urease activity was measured by indophenol blue colorimetry [12], soil sucrase activity was measured by 3, 5-dinitrosalicylic acid colorimetry [12], and soil catalase activity was determined by potassium permanganate titration Method [12], soil polyphenol oxidase activity was measured by colorimetric method [13].

\section{Results and Discussion}

Soil Catalase Activity. Under Cd stress, C. betacea intercropping $S$. photeinocarpum, soil catalase was significantly different from $\mathrm{CK}(P<0.05)$, but there was no significant difference among the intercropping treatments $(P<0.05)$. T1, T2, T3, and T4 compared with $C$. betacea seedlings decreased by $12.63 \%, 13.53 \%, 19.50 \%$ and $15.78 \%$ (Fig. 1 ).

Soil Polyphenol Oxidase Activity. Under Cd stress, C. betacea intercropping S. photeinocarpum, soil polyphenol oxidase improved significantly $(P<0.05)$. T3 and T4 were significantly higher than 
$\mathrm{T} 1$ and T2. The results showed that the soil polyphenol oxidase value was the highest $\left(0.241 \mathrm{ml} \cdot \mathrm{g}^{-1}\right)$ when T3 was processed (Fig. 2).

Soil Sucrase Activity. As can be seen from Fig. 3, soil sucrase was significantly increased except T1 $(P<0.05)$. T3 soil sucrase reached the highest level, 49.62\% $(P<0.05)$ higher than $C$. betacea.

Soil Urease Activity. As can be seen from Fig. 4, the soil urease activity of T3 and T4 increased significantly by $27.45 \%$ and $17.69 \%(P<0.05)$. Nevertheless, T1 and T2 didn't increase soil urease activity $(P<0.05)$.

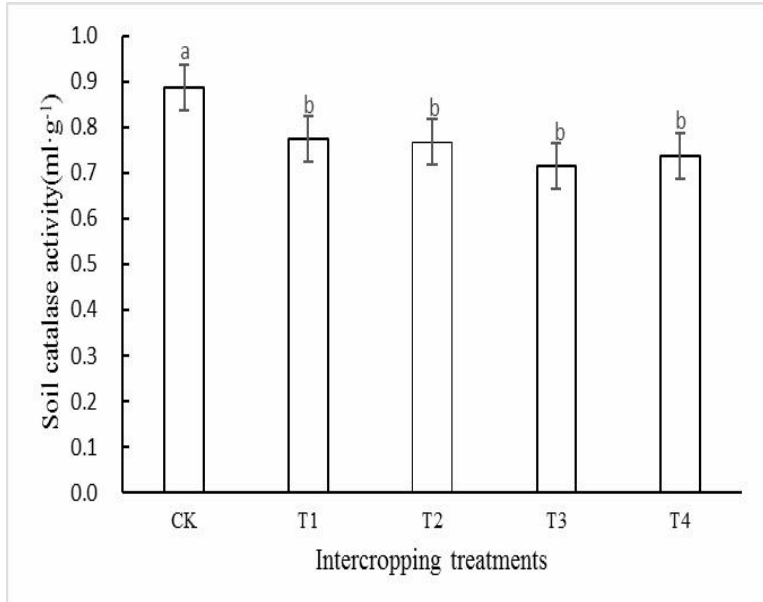

Fig. 1 Soil catalase activity

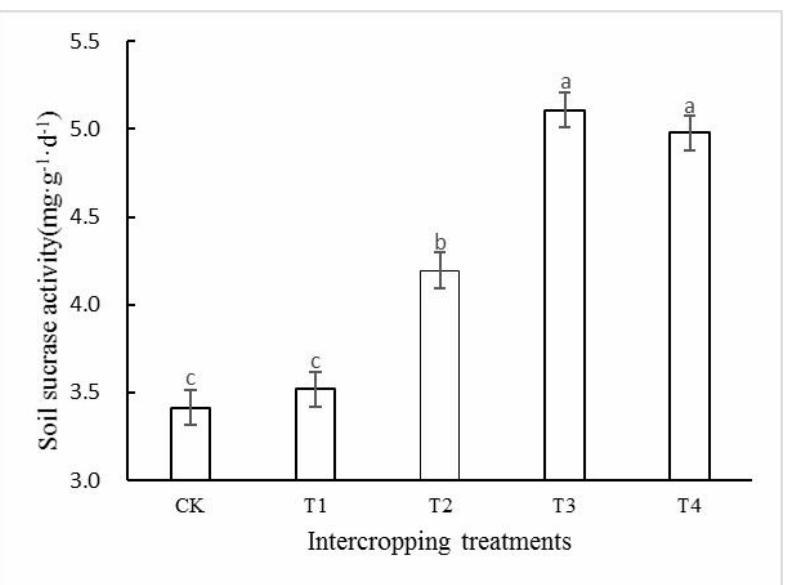

Fig. 3 Soil sucrase activity

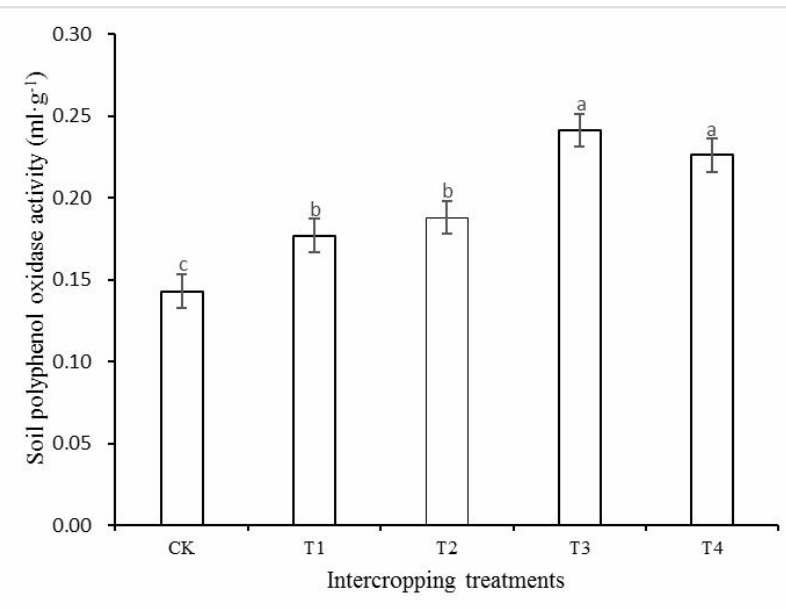

Fig. 2 Soil polyphenol oxidase activity

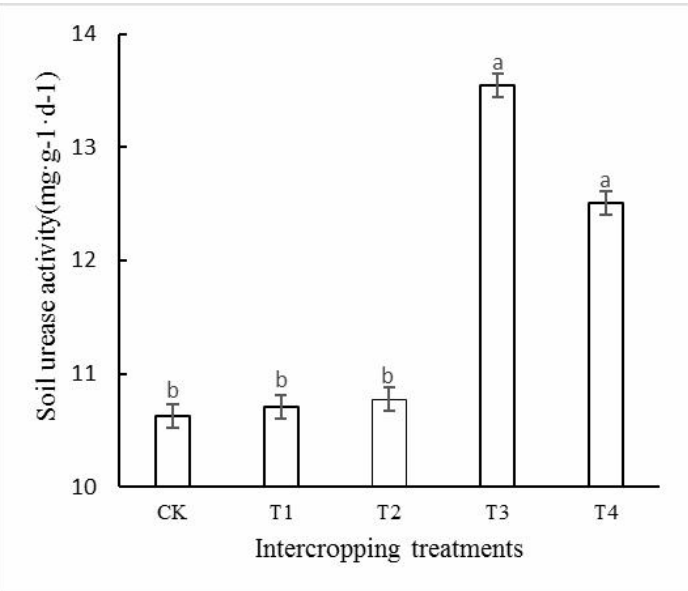

Fig. 4 Soil urease activity

\section{Conclusions}

C. betacea intercropping two ecotypes of $S$. photeinocarpum and their hybridization F1 generation had different effects on improving soil enzyme activities. Among them, the improvement of soil enzyme activity after $C$. betacea intercropped two ecotypes of $S$. photeinocarpum hybridization F1 generation was better than that of $C$. betacea intercropping two ecotypes of $S$. photeinocarpum, which indicated that the root exudates of $C$. betacea intercropping two ecotypes of $S$. photeinocarpum had limitations on the improvement of Cd-contaminated soil environment, while two ecotypes of $S$. photeinocarpum hybridization $\mathrm{F}_{1}$ generation can break this limitation and further improve the soil environment. Therefore, two ecotypes of $S$. photeinocarpum hybridization $\mathrm{F}_{1}$ generation were most beneficial to the ecological environment of Cd-contaminated soils improvement in this experiment.

\section{Acknowledgements}

This work was financially supported by the Application Infrastructure Project of Science and Technology Department of Sichuan Province (2016JY0258). 


\section{References}

[1] Q. Dong, Z. He, Y.P. XU, X.M. Zhang and C.Y. Li: Seeds Vol. 31 (2012), p. 50.

[2] B.Y. Guo, W.H. Zhou, Q.L. Ye and B.H. Huang: Guangdong Agricultural Sciences Vol. 12 (2007), p. 102.

[3] A.P.G.C. Marques, A.O.S.S. Rangel and P.M.L. Castro: Reviews in Environmental Science and Technology Vol. 39 (2009), p. 622.

[4] C.Y. Li, X.H. He, S.S. Zhu, H.P. Zhou, Y.Y. Wang, Y. Li, J. Yang, J.X. Fan, J.C. Yang, G.B. Wang, Y.F. Long, J.Y. Xu, Y.S. Tang, G.H. Zhao, J.R. Yang, L. Liu, Y. Sun, Y. Sun, Y. Xie, H.N. Wang and Y.Y. Zhu: PloS One Vol. 4 (2009), p. e8049.

[5] Y.N. Song, F.S. Zhang, P. Marschner, F.L. Fan, H.M. Gao, X.G. Bao, J.H. Sun and L. Li: Biology and Fertility of Soils Vol. 43 (2007), p. 565.

[6] C.J. Li, W. Ma and F.S. Zhang: Journal of Plant Nutrition and Fertilizer Vol. 14 (2008), p. 178.

[7] Q.H. Chai, P. Huang and G.B. Huang: Acta Prataculturae Sinica Vol. 14 (2005), p. 105.

[8] Z.X. YANG, S.D. Feng and S.Q. Liu: Chinese Journal of Eco-Agriculture Vol. 13 (2005), p. 138.

[9] H. Yang, S.Q. Liu and B.W. Li: Hebei Environmental Science Vol. 12 (2004), p. 16.

[10] Y.H. Li, L.G. Zong, Y. Huang and Y.H. Zhao: Journal of Nanjing Agricultural University, Vol. 25 (2002), p. 45.

[11] Shen Z G, Zhao F J and McGrath S P: Plant, Cell \& Environment Vol. 20 (1997), p. 898.

[12]L.K. Zhou: Soil Enzymology (Science Press, Beijing 1987).

[13]Y.S. Guan: Soil Enzymes and Research Methods (Agricultural Press, Beijing 1986). 